\title{
Comment to Rull et al. (2013) - Challenging Easter Island's Collapse: the need for interdisciplinary synergies
}

\author{
Annegret Larsen ${ }^{1,2 *}$ and Dale F. Simpson Jr. ${ }^{2,3,4}$ \\ ${ }^{1}$ Ecosystem Science and Geoarchaeology, Institute of Ecosystem Science, University of Kiel, Kiel, Germany \\ ${ }^{2}$ Archaeology, School of Social Science, University of Queensland, St. Lucia, Australia \\ ${ }^{3}$ Anthropology, The College of DuPage, Glen Ellyn, Illinois, USA \\ ${ }^{4}$ Manu Iri-Rapa Nui Heritage Guardians, Terevaka Archaeological Outreach, Ka'ara Environmental Conscience, Hanga Roa, Chile \\ *Correspondence: alarsen2@uq.edu.au
}

Edited by:

Christopher Carcaillet, Ecole Pratique des Hautes Etudes, France

Reviewed by:

Scott David Mooney, University of New South Wales, Australia

Janet Wilmshurst, Landcare Research, New Zealand

Christopher Carcaillet, Ecole Pratique des Hautes Etudes, France

Keywords: Easter Island, interdisciplinarity, collapse, social change, environmental changes

\section{A commentary on}

Challenging Easter Island's collapse: the need for interdisciplinary synergies

by Rull, V., Cañellas-Boltà, N., Sáez, A., Margalef, O., Bao, R., Pla-Rabes, S., et al. (2013). Front. Ecol. Evol. 1:3. doi: 10.3389/ fevo.2013.00003

The road to deforestation and its social feedback on Rapa Nui is a fascinating and a possibly important parable; one with symbolic implications for how the rest of the world views environmental change and human impact. Rull et al. (2013) present a compilation and critique of Rapa Nui's paleoecological and archeological data that is critical for progressing further work on the island, and state that Rapa Nui was subject of a gradual environmental change instead of rapid deforestation. The authors interpret the slower pace of deforestation as evidence for gradual social change, supported by Mulrooney (2013) recent archeological investigation in La Pérouse Bay (Figure 1), therefore contradicting the hypothesis of an abrupt ecocidal collapse of Easter Island's prehistoric society (Diamond, 1994). In order to advance their interpretations, the authors suggest a closer collaboration between archeology and paleoecology and propose a research agenda.

It is important to understand that past environmental change provides limited conclusions in regards to societal change, as societies have the ability to adapt.
However, paleoecological information derived from the island's lake records (Rano Aroi, Rano Raraku, and Rano Kau; Figure 1) is well established and used as the main evidence to support the island's proposed collapse (Bahn and Flenley, 1992; Diamond, 2005). But, the limitations of palynological interpretation are well known and widely discussed in the scientific community (Flenley et al., 1991; Ritchie, 1995; Hunter-Anderson, 1998; Blarquez et al., 2013). Thus, a call for closer collaboration between archeology and paleoecology is somewhat surprising. Instead, we suggest that a widening of disciplines in order to use a varied range of interpretive techniques, and a multiplicity of environmental and archeological archives, would be of much greater advantage in order to understand the heavily discussed past of Rapa Nui (Förster et al., 2013).

Rull et al. (2013) set up a research agenda which presumes common questions between archeology and paleoecology based on a summary of previous work. However, this summary seemed to be focused on selected archeological publications, and furthermore dismissed paleoecological data from archives other than lake records. As a result, the authors:

1. Point out that there is new evidence for a gradual deforestation of the island, instead of abrupt ecological change. To our knowledge however, the majority of scientists have not actually proposed rapid deforestation, but for the process lasting $\sim 400$ of years or longer (Hunter-Anderson, 1998; Orliac, 2000; Mieth and Bork, 2004, 2005; Mann et al., 2008; Hunt and Lipo, 2010). In addition, there is strong evidence in Poike (Figure 1) for a slash-and-burn gardening culture, coexisting with palm dominated forests which pre-dates deforestation (Mieth and Bork, 2005, 2010).

2. Set the island's original colonization, based on the indirect evidence of the presence of Verbena litoralis, some $\sim 1500$ years before the currently held dates between AD 1100-1200 (Mulrooney et al., 2011; Weisler and Green, 2011). Rull et al. (2013) proposed colonization date is also in direct contradiction of refined dating through the radiometric hygiene protocol (Spriggs and Anderson, 1993; Hunt and Lipo, 2007; Wilmshurst et al., 2011), where most Polynesian archeologists agree that almost all islands were navigated to and settled much later than initial dispersal models have indicated (Kirch, 1984). While we agree that more data should be used to corroborate initial settlement (and not ceramics as they do not exist on Rapa Nui), using only one botanical proxy which is indirect at best, to determine the complex timing and process of Pacific island colonization (Irwin, 1992), is tenuous. 


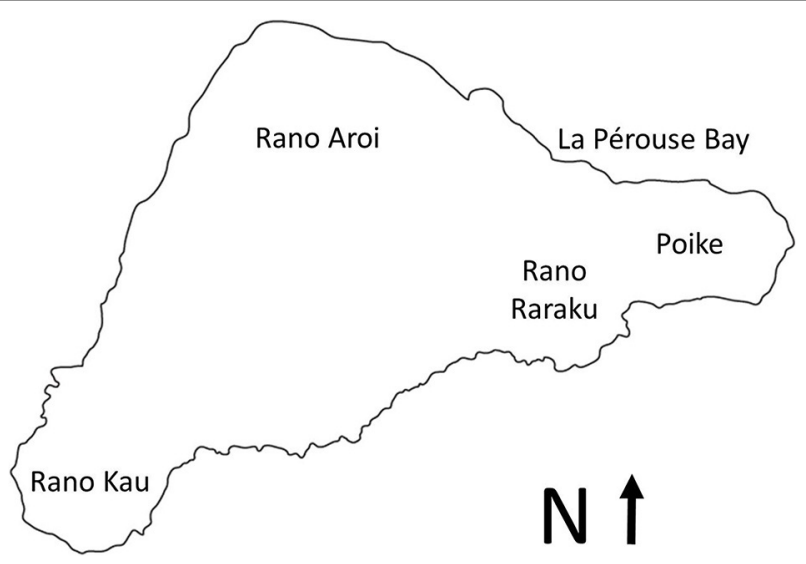

FIGURE 1 | Locations on Rapa Nui (Easter Island) referred to in this comment.

3. Fail to mention Mulrooney et al. (2009, 2010) earlier work which outlines the archeological fallacies of the collapse model.

4. State that: "archeological and anthropological research has rarely addressed the potential role of environmental changes, specifically climatic, as potential drivers for social transformations on the island" (Rull et al., 2013; P. 3). While Orliac and Orliac (1998) suggested that climatically induced drought and subsequent fires were important factors in the island's prehistory, Hunt and Lipo (2001) used archeological and ecological data to position Rapa Nui in an "unpredictable environment" which encouraged prehistoric inhabitants to practice "wasteful" bet-hedging behavior. Hunter-Anderson (1998) presented a "geo-climatic" model where climatic deterioration was characterized by prolonged and severe droughts during the Little Ice Age (see also Mccall, 1993), and late Holocene migration across the Pacific Ocean might be related to ENSO (El Niño-Southern Oscillation) (Anderson et al., 2006).

5. Provide no discussion about the island's paleodemography and the peak number of prehistoric inhabitants. While this number is debated, the difference between 3000 (Hunt, 2006) and 20,000 (Bahn and Flenley, 1992) occupants has huge connotations for synergetic interpretations of land and resource use and the relationship between the ancient Rapanui and their island environment.
6. Ignore the role that disasters such as tsunamis, earthquakes, flooding, Pacific volcanism and sea level changes could have played in acerbating social and environmental transformation (Nunn, 2000; Dickinson, 2003; Goff et al., 2012; Pakarati, 2014).

7. Omit the role the Polynesian rat (Rattus exulans) played in dampening tree regeneration (Hunter-Anderson, 1998; Bork and Mieth, 2003; Hunt and Lipo, 2007) and the possible appearances of fungus and tree and plant diseases which might have also stunted regeneration and growth (Shepardson, 2013), and finally.

8. Do not consider the catastrophic impact brought to the island by early visitors and colonizers in the form of social change, disease, kidnapping, and murder (Peiser, 2005).

We fully agree with the call of this paper for more scientific fields to collaborate together to help better interpret the (pre)history of Easter Island. However, with the limitations of Rapa Nui's lake records and an already intensive archeological data collection in a high temporal and spatial resolution, the engagement of all abundant archives (such as soils, fluvial and marine sediments, and records of disasters) with paleoenvironmental proxies (such as geochemistry and geophysics) has huge potential to overcome shortcomings of the existing paleo-records. An involvement of more research fields will therefore reveal more than an intensive communication between paleoecology and archeology and might demonstrate that although the (pre)historic Rapanui are alleged to be a collapsed culture bounded by socio-political competition, ecological overexploitation and megalithic overproduction, the discussion would be better served if it recognized the Rapanui as a Polynesian island culture of adaptation and survival that has thrived for almost a millennium (Simpson, 2013).

\section{REFERENCES}

Anderson, A., Chappell, J., Gagan, M., and Grove, R. (2006). Prehistoric maritime migration in the Pacific islands: an hypothesis of ENSO forcing. Holocene 16, 1-6 doi: 10.1191/0959683606hl $901 \mathrm{ft}$

Bahn, P., and Flenley, J. (1992). Easter Island, Earth Island. London: Thames and Hudson.

Blarquez, O., Finsinger, W., and Carcaillet, C. (2013). Assessing paleo-biodiversity using low proxy influx. PLOS ONE 8:e65852. doi: 10.1371/journal.pone.0065852

Bork, H.-R., and Mieth, A. (2003). The key role of Jubaea palm trees in the history of Rapa Nui: a provocative interpretation. Rapa Nui J. 17, 119-122.

Diamond, J. M. (1994). Ecological collapses of ancient civilizations: the golden age that never was. Bull. Am. Acad. Arts Sci. 47, 37-59. doi: $10.2307 / 3824451$

Diamond, J. M. (2005). Collapse. How Societies Choose to Fail or Succeed. New York, NY: Penguin.

Dickinson, W. R. (2003). Impact of mid-Holocene hydro-isostatic highstand in regional sea level on habitability of islands in Pacific Oceania. J. Coast. Res. 19, 489-502.

Flenley, J. R., King, A. S. M., Jackson, J., Chew, C., Teller, J. T., and Prentice, M. E. (1991). The Late Quaternary vegetational and climatic history of Easter Island. J. Q. Sci. 6, 85-115. doi: 10.1002/jqs.3390060202

Förster, F., Großmann, R., Hinz, M., Iwe, K., Kinkel, H., Larsen, A., et al. (2013). Towards mutual understanding within interdisciplinary palaeoenvironmental research: an exemplary analysis of the term landscape. Q. Int. 312, 4-11. doi: 10.1016/j.quaint.2013.07.045

Goff, J., Mcfadgen, B. G., Chagué-Goff, C., and Nichol, S. L. (2012). Palaeotsunamis and their influence on Polynesian settlement. Holocene 22, 1067-1069. doi: 10.1177/0959683612437873

Hunt, T. (2006). Rethinking the Fall of Easter Island. Am. Sci. 94, 412-419. doi: 10.1511/2006.61.1002

Hunt, T., and Lipo, C. (2001). "Cultural elaboration and environmental uncertainty in polynesia," in Pacific 2000-Proceedings of the Fifth International Conference on Easter Island and the Pacific, eds C. M. Stevenson, G. Lee, and E. J. Morin (Los Osos, CA: Easter Island Foundation).

Hunt, T., and Lipo, C. (2007). Chronology, deforestation, and "collapse": Evidence vs. faith in Rapa Nui prehistory. Rapa Nui J. 21, 85-97.

Hunt, T., and Lipo, C. (2010). "Ecological catastrophe, collapse, and the myth of "Ecocide" on Rapa Nui (Easter Island)," in Questioning CollapseHuman Resilience, Ecological Vulnerability, and the Aftermath of Empire, eds P. A. McAnany and 
N. Yoffee (New York, NY: Cambridge University Press), 223-246.

Hunter-Anderson, R. L. (1998). "Human vs. climatic impacts at Rapa Nui: did the people really cut down all those trees?" in Easter Island in Pacific Context; South Seas Symposium, eds C. M. Stevenson, G. Lee, and E. J. Morin (Los Osos, CA: Easter Island Foundation).

Irwin, G. (1992). The Prehistoric Exploration and Colonization of the Pacific. Cambridge: Cambridge University Press).

Kirch, P. V. (1984). The Evolution of the Polynesian Chiefdom. Cambridge: Cambridge University Press.

Mann, D., Edwards, J., Chase, J., Beck, W., Reanier, R., Mass, M., et al. (2008). Drought, vegetation change, and human history on Rapa Nui (Isla de Pascua, Easter Island). Q. Res. 69, 16-28. doi: 10.1016/j.yqres.2007.10.009

Mccall, G. (1993). Little ice age: some speculations for Rapa Nui. Rapa Nui J. 7, 65-70.

Mieth, A., and Bork, H.-R. (2004). Easter Island-Rapa Nui: Scientific Pathways to Secrets of the Past. Kiel: Ecology Centre University of Kiel.

Mieth, A., and Bork, H.-R. (2005). History, origin and extent of soil erosion on Easter Island (Rapa Nui). Catena 63, 244-260. doi: 10.1016/j.catena.2005.06.011

Mieth, A., and Bork, H.-R. (2010). Humans, climate or introduced rats-which is to blame for the woodland destruction on prehistoric Rapa Nui (Easter Island)? J. Archaeol. Sci. 37, 417-426. doi: 10.1016/j.jas.2009. 10.006

Mulrooney, M. A. (2013). An island-wide assessment of the chronology of settlement and land use on Rapa Nui (Easter Island) based on radiocarbon data. J. Archaeol. Sci. 40, 4377-4399. doi: 10.1016/j.jas.2013.06.020

Mulrooney, M. A., Bickler, S. H., Allen, M. S., and Ladefoged, T. N. (2011). High-precision dating of colonization and settlement in East Polynesia. Proc. Natl. Acad. Sci. U.S.A. 108, 192-194. doi: 10.1073/pnas.1100447108
Mulrooney, M. A., Ladefoged, T. N., Stevenson, C. M., and Haoa, S. (2009). The Myth of AD 1680: new evidence from Hanga Ho'onu, Rapa Nui (Easter Island). Rapa Nui J. 23, 94-105.

Mulrooney, M. A., Ladefoged, T. N., Stevenson, C. M., and Haoa, S. (2010). "Empirical assessment of a pre-European societal collapse on Rapa Nui (Easter Island)," in The Gotland Papers: Selected Papers from the VII International Conference on Easter Island and the Pacific: Migration, Identity, and Cultural Heritage, eds P. Wallin and $\mathrm{H}$. Martinsson-Wallin (Gotland: Gotland University Press).

Nunn, P. D. (2000). Environmental catastrophe in the Pacific Islands around A.D. 1300. Geoarchaeology 15, 715-740. doi: 10.1002/1520-6548(200010)15: 7\%3C715::AID-GEA4\%3E3.0.CO;2-L

Orliac, C. (2000). "The woody vegetation of Easter Island between the early 14th and the mid-17th centuries AD," in Easter Island in Pacific Context; South Seas Symposium, eds C. M. Stevenson, G. Lee, and E. J. Morin (Los Osos, CA: Easter Island Foundation)

Orliac, C., and Orliac, M. (1998). "The disappearance of Easter Island's forest: over-exploitation or climatic catastrophe?" in Easter Island in Pacific Context; South Seas Symposium, eds C. M. Stevenson, G. Lee, and E. J. Morin (Los Osos, CA: Easter Island Foundation).

Pakarati, C. M. (2014). Tsunamis on Rapa Nui. Hanga Roa: Moe Varua.

Peiser, B. (2005). From genocide to ecocide: the Rape of Rapa Nui. Energy Environ. 16, 513-540. doi: 10.1260/0958305054672385

Ritchie, J. C. (1995). Current trends in studies of longterm plant community dynamics. New Phytol. 130, 469-494. doi: 10.1111/j.1469-8137.1995. tb04325.x

Rull, V., Canellas-Bolta, N., Saez, A., Margalef, O. Bao, R., Pla-Rabes, S., et al. (2013). Challenging Easter Island's collapse: the need for interdisciplinary synergies. Front. Ecol. Environ. 1:3. doi $10.3389 /$ fevo.2013.00003
Shepardson, B. L. (2013). Moai: a New Look at Old Faces. Santiago: Rapa Nui Press.

Simpson, J. D. (2013). "Do people still live on Easter Island?," in Collapse Versus Progress. A Paper Presented at the University of Queensland's Perspectives on Progress Conference (Brisbane, QLD).

Spriggs, M., and Anderson, A. (1993). Late colonization of east Polynesia. Antiquity 67, 200-217.

Weisler, M. I., and Green, R. (2011). Rethinking the chronology of colonization of southeast polynesia" in Polynesians in America, eds T. Jones, A. Storey, E. Matisoo-Smith, and J. M. Ramirez-Aliaga (New York, NY: Alta Mira Press), 26-30.

Wilmshurst, J. M., Hunt, T. L., Lipo, C. P., and Anderson, A. J. (2011). High-precision radiocarbon dating shows recent and rapid initial human colonization of East Polynesia. Proc Natl. Acad. Sci. U.S.A. 108, 1815-1820. doi: 10.1073/pnas. 1015876108

Conflict of Interest Statement: The authors declare that the research was conducted in the absence of any commercial or financial relationships that could be construed as a potential conflict of interest.

Received: 09 July 2014; accepted: 22 August 2014; published online: 15 September 2014.

Citation: Larsen A and Simpson DF Jr. (2014) Comment to Rull et al. (2013)—Challenging Easter Island's Collapse: the need for interdisciplinary synergies. Front. Ecol. Evol. 2:56. doi: 10.3389/fevo. 2014.00056

This article was submitted to Paleoecology, a section of the journal Frontiers in Ecology and Evolution.

Copyright (0) 2014 Larsen and Simpson. This is an open-access article distributed under the terms of the Creative Commons Attribution License (CC BY). The use, distribution or reproduction in other forums is permitted, provided the original author(s) or licensor are credited and that the original publication in this journal is cited, in accordance with accepted academic practice. No use, distribution or reproduction is permitted which does not comply with these terms. 